\title{
Circumstances of Discovery of Arterial Hypertension (AHT) in a Department of Internal Medicine in Lomé (Togo)
}

\author{
Komi Dzidzonu Nemi ${ }^{1,4 *}$, Lihanimpo Djalogue ${ }^{2,5}$, Abou-Bakari \\ Tchala $^{1}$, Kodjo Agbeko Djagadou ${ }^{1,4}$, Toyi Tchamdja ${ }^{2,5}$, Yawovi \\ Mawufemo Tsevi ${ }^{3,4}$, Komi Edem Mossi ${ }^{1}$, Abdou Razak Moukaila1, \\ Abago Balaka ${ }^{1,4}$ and Mohaman Awalou Djibril ${ }^{1,4}$ \\ ${ }^{1}$ Department of Internal Medicine, Sylvanus Olympio Teaching Hospital of Lomé, \\ Togo \\ ${ }^{2}$ Department of Internal Medicine, Kara Teaching Hospital, Togo \\ ${ }^{3}$ Department of Nephrology, Sylvanus Olympio Teaching Hospital of Lomé, Togo \\ ${ }^{4}$ University of Lomé, Togo \\ ${ }^{5}$ University of Kara, Togo \\ *Corresponding Author: Komi Dzidzonu Nemi, Department of Internal Medicine, \\ Sylvanus Olympio Teaching Hospital of Lomé, University of Lomé, Togo.
}

\author{
Received: July 20, 2020 \\ Published: September 25, 2020 \\ (C) All rights are reserved by Komi Dzidzonu \\ Nemi., et al.
}

\begin{abstract}
The aim of this study was to describe the circumstances in which arterial hypertension was discovered in known non-hypertensive patients admitted to the Internal Medicine department of the Sylvanus Olympio teaching hospital of Lomé. It is a retrospective and descriptive study conducted from $1^{\text {st }}$ January 2015 to 31 December 2017 from the files of patients with hypertension in whom the diagnosis of hypertension was made in the Internal Medicine department. During the period of study, 176 patients suffering from arterial hypertension were received in the department. Among them, 105 were not known to have hypertension. The average age was 55, 69 years (extremes of 20 and 89 years) with a sex ratio (M/F) of 0,90. Hypertension was essential in 97, 14\% (N = 102) and secondary in $2.85 \%$ of cases $(\mathrm{N}=3)$. It was grade 1 in $28,57 \%(\mathrm{~N}=30)$; grade 2 in $44,76 \%(\mathrm{~N}=47)$ and grade 3 in $26,66 \%$ of cases $(\mathrm{N}=28)$. Cardiovascular risk factors associated with hypertension were diabetes mellitus $(55,23 \%)$, obesity $(15,23 \%)$, dyslipidaemia $(8,57 \%$, family history of hypertension $(7,62 \%)$ and alcoholism $(6,67 \%)$. The discovery of hypertension has been fortuitous in $79,19 \%$ of cases $(\mathrm{N}=80)$. It has been revealed by symptoms in $13,33 \%(\mathrm{~N}=14)$ and by complications in $10.47 \%$ of cases $(\mathrm{N}=$ 11). hypertension unknown is frequent in the Internal Medicine department of the Sylvanus Olympio Teaching Hospital, especially in diabetics. More emphasis must be placed on its prevention in our country by promoting new methods of raising awareness and educating the population.
\end{abstract}

Keywords: High Blood Pressure; Fortuitous Discovery; Diabetes Mellitus; Lomé (Togo)

\section{Introduction}

A major cardiovascular risk factor in the world, arterial hypertension is defined by systolic blood pressure (SBP) $\geq 140 \mathrm{mmHg}$ and/or diastolic blood pressure (DBP) $\geq 90$ [1]. For a long time, hypertension was considered as a rare or even non-existent pathology among the populations of the various African States [2].
Then, from 1944 and gradually, another current of opinion, quite opposite, emerged [2]. Today, it is a major concern in developing countries and particularly in Sub-Saharan Africa, no doubt due to the aging of the population, the phenomenon of urbanization and changes in lifestyle $[3,4]$. Togo is no exception. In our country, hypertension affects all races, all ethnic groups and all socio-profes- 
sional strata [5] and its prevalence was estimated at 22\% in urban and suburban areas in the south of the country in 2008 [6], 41.6\% in the northern region in 2009 [7] and 19\% across the country in 2010 [8]. But in most cases, it remains asymptomatic for a long time and therefore often goes unrecognized [6] and often reveals itself through complications [9]. This work aims to describe the different circumstances of discovery of the disease in an Internal Medicine environment in Lomé.

\section{Patients and Methods}

It is a retrospective and descriptive study which was held in the department of Internal Medicine of the Sylvanus Olympio teaching hospital of Lomé. It has extended over a period of three years from 1 January 2015 to 31 December 2017. Have been included in this study, patients with hypertension whose diagnosis has been made in the service. The diagnosis of hypertension has been made on the basis of a blood pressure in both arms with a systolic greater than or equal to $140 \mathrm{mmHg}$ and/or the diastolic greater than or equal to $90 \mathrm{mmHg}$ twice. The parameters studied were epidemiological data (prevalence, age, sex, risk factors), grades and types of hypertension and the different circumstances of discovery of hypertension.

\section{Results}

\section{Epidemiology}

During our study period, 176 patients with hypertension have been recorded in the service. Among them 105 were not known hypertensive, a prevalence of $59.65 \%$ of unknown hypertension. The average age was 55.69 years (range: 20 and 89 years). The sex ratio $(\mathrm{M} / \mathrm{F})$ was 0.90 .

\section{Other cardiovascular risk factors associated}

The diabetes was the first cardiovascular risk factors associated $(55,23 \%)$ followed by obesity $(15,23 \%)$ and dyslipidaemia $(8,57 \%)$ (Table 1$)$.

\section{Grades of hypertension}

Hypertension was grade 1 in $28.57 \%(\mathrm{~N}=30)$; grade 2 in $44.76 \%(\mathrm{~N}=47)$ and grade 3 in $26.66 \%$ of cases $(\mathrm{N}=28)$.

\section{Type of hypertension}

Hypertension was essential in $97.14 \%(\mathrm{~N}=102)$ and secondary in $2.85 \%$ of cases $(\mathrm{N}=3)$.

\begin{tabular}{|l|c|c|}
\hline & Effective & Percentage \\
\hline Diabetes & 17 & 16.19 \\
\hline Diabetes + obesity & 7 & 6.7 \\
\hline Diabetes + dyslipidaemia & 5 & 4.76 \\
\hline $\begin{array}{l}\text { Diabetes + family history of hyperten- } \\
\text { sion }\end{array}$ & 4 & 3.81 \\
\hline Diabetes + alcohol & 7 & 6.7 \\
\hline Diabetes + microproteinuria & 6 & 5.71 \\
\hline Diabetes + macroproteinuria & 3 & 2.85 \\
\hline Obesity + dyslipidaemia & 4 & 3.81 \\
\hline $\begin{array}{l}\text { Obesity + family history of hyperten- } \\
\text { sion }\end{array}$ & 4 & 3.81 \\
\hline Obesity + hyperuricemia & 1 & 0.95 \\
\hline HIV & 4 & 3.81 \\
\hline Stress & 3 & 2.85 \\
\hline Tobacco & 2 & 1.91 \\
\hline Hyperuricemia & 1 & 0.95 \\
\hline Lack of risk factor & 5 & 4.76 \\
\hline Unspecified & 32 & 30.47 \\
\hline Total & & 100 \\
\hline
\end{tabular}

Table 1: Distribution of patients according to the cardiovascular risk factors associated.

\section{Circumstances of discovery}

The discovery of hypertension has been fortuitous in $79,19 \%$ of cases $(\mathrm{N}=80)$ (Table 2$)$.

\begin{tabular}{|l|c|c|}
\hline & Effective & Percentage \\
\hline Complicated diabetes & 25 & 31.25 \\
\hline Unbalanced diabetes & 25 & 31.25 \\
\hline Diabetic follow-up visit & 8 & 10 \\
\hline Abdominal pain & 9 & 11.25 \\
\hline Infectious syndrome & 8 & 10 \\
\hline Low back pain & 2 & 2.5 \\
\hline Liver cirrhosis & 2 & 2.5 \\
\hline Pleurisy & 1 & 1.25 \\
\hline Total & 80 & 100 \\
\hline
\end{tabular}

Table 2: Distribution of patients according to the fortuitous discovery of hypertension. 
Hypertension was revealed by symptoms in $13,33 \%(\mathrm{~N}=14)$ : Table 3 and by complications in 10, 47\% ( $=11$ ) (Table 4).

\begin{tabular}{|l|c|c|}
\hline & Effective & Percentage \\
\hline Headache & 9 & 64.3 \\
\hline Headache + dizziness & 3 & 21.4 \\
\hline Headache + vertigo + tinnitus & 1 & 7.1 \\
\hline Palpitation & 1 & 7.1 \\
\hline Total & 14 & 100 \\
\hline
\end{tabular}

Table 3: Distribution of patients in function of symptoms revealing hypertension.

\begin{tabular}{|l|c|c|}
\hline & Effective & Percentage \\
\hline Ischemic stroke & 2 & 18.18 \\
\hline Haemorrhagic stroke & 1 & 9.09 \\
\hline Hypertension encephalopathy & 2 & 18.18 \\
\hline Heart failure & 4 & 36.36 \\
\hline Chronic renal failure & 2 & 18.18 \\
\hline Total & 11 & 100 \\
\hline
\end{tabular}

Table 4: Breakdown of patients in function of complications revealing hypertension.

\section{Discussion}

We noted a prevalence of $59.65 \%$ for the unknown hypertension compared to all hypertensive patients admitted to our department. This prevalence is close to that reported in the French population in 2015 , i.e. $55 \%$ [10]. On the other hand, it is clearly higher than the $26 \%$ reported by Yao., et al. in an Internal Medicine department in Côte d'Ivoire [9]. This difference could be explained by the particularity of the Ivorian study which concerned only de novo complicated hypertension. Our study population consisted mainly of young adults, as in most series regardless of the types of work in the general population [3,6,8-11]. A slight female predominance was observed in our patients. The sex ratio is variously reported by the authors $[3,6,9,11-14]$. However, the prevalence of hypertension would be higher in the black Caribbean $[13,14]$ and sub-Saharan African $[3,11]$ female population than in the white population $[10,13]$ suggesting the existence of a racial and cultural factor. In our series, diabetes mellitus was the main cardiovascular risk factor associated with hypertension in 55.23\% of cases. In fact, hypertension is frequent in type 2 diabetes $[15,16]$. Prevalences reported in Africa vary from 40.67 to $81 \%$ [16]. Obesity was the second cardiovascular risk factor associated with hypertension in our patients. In fact, the risk of developing hypertension appears to be significantly greater in the overweight or obese population $[3,17]$ and the proportional increase in the body mass index and the prevalence of hypertension generally follows the degree of westernization and way of life [17]. In Togo, obesity is considered a criterion of beauty and a sign of ease. This would partly explain the predominance of hypertension in women in our country $[6,8]$. The other cardiovascular risk factors observed in our patients notably dyslipidaemia, family history of hypertension, alcohol, microproteinuria/proteinuria, HIV infection, stress and smoking have also been reported by authors but with various frequency [6,18-22]. Grade 2 hypertension was predominant in our study (44.76\%), confirming data from two other Togolese series [6,20]. Regarding type, hypertension was essential in the majority of cases in our series. This is classically known [18].

The discovery of hypertension was fortuitous in $79,19 \%$ of cases in our study population. It was in the majority of cases $(72.5 \%)$ in diabetics. As pointed out above, hypertension is one of the most frequent macroangiopathic complications of diabetes mellitus $[23,24]$. The association of these two pathologies increases the cardiovascular risk $[15,16]$ hence the need not only for regular monitoring of blood pressure and other cardiovascular risk factors in diabetics but also for diabetic education quality in order to avoid or delay the onset of hypertension in these patients. The discovery was also fortuitous in our series in $27.5 \%$ of cases in patients hospitalized or received in outpatient for various pathologies. This shows the importance of the systematic taking of blood pressure to any patient received in consultation since some of our patients have benefited from recent specialized consultations before their admission to our service. Hypertension was revealed by symptoms in $13.33 \%$ of cases in our series with headaches as the leader. Our results are in agreement with the data of the Togolese $[6,20]$ and Rwanda [21] series. The other symptoms revealing hypertension in our study were vertigo, palpitations, and tinnitus. These symptoms have also been reported by authors, but with varying frequencies $[18,20,21]$. The complications that reveal the disease are classic. It is essentially about the attack of the target organs like the brain, the eye, the heart and the kidney. However, the frequency of impact of hypertension on these organs differs from one study to another. In our work, the various complications revealing it were respectively neurological, cardiac and renal, thus joining the data of the series of Ukoh., et al. in 2007 in Nigeria [25]. In Côte d'Ivoire [9], the main complications of de novo hypertension were respec- 
tively renal, neurological, and cardiac. In Burkina Faso, cardiac complications came first, followed by kidney damage [26]. In our series, among the neurological complications, the ischemic stroke was predominant confirming the data from the literature according to which arterial hypertension puts more at risk of ischemic stroke than haemorrhagic $[27,28]$. Renal impairment in our patients was represented by renal failure as in most series [9,11,25-27]. Concerning heart attacks, it was about heart failure. Pio., et al. made the same observation in our hospital in 2014 but in a cardiological environment [29].

\section{Conclusion}

The unknown hypertension is frequent in the department of internal medicine (Medicine B) of the Sylvanus Olympio teaching hospital of Lomé. Its gravity is linked to its impact on organs targets hence the need to emphasize more not only on its prevention but also on that of the other cardiovascular risk factors through the use of new methods of information and education of the Togolese population in general and diabetics in particular.

\section{Conflicts of Interest}

None.

\section{Bibliography}

1. Mancia G., et al. "ESH/ESC Guidelines for the management of arterial hypertension: The Task Force for the management of arterial hypertension of the European Society of Hypertension (ESH) and of the European Society of Cardiology (ESC)". Journal of Hypertension 31.7 (2013): 1281-357.

2. Koate A. "L'hypertension artérielle en Afrique noire". Bulletin de l'Organisation mondiale de la Sante 56.6 (1978): 841-848.

3. Fourcade L., et al. "Hypertension artérielle en Afrique Subsaharienne actualité et perspectives”. Medica Tropical 67 (2007): 559-567.

4. Addo J., et al. "Hypertension in sub-Saharan Africa: a systematic review". Hypertension 50.6 (2007): 1012-1018.

5. Agence national d'accélération et d'évaluation en santé. "Prise en charge des patients atteints d'hypertension artérielle". Rapport ANAES: Avril (2001).

6. Damorou F., et al. "Epidémiologie et circonstance de découverte de l'hypertension artérielle en milieu hospitalier à Kpalimé (ville secondaire du Togo)". Mali Médical 23 (2008): 17-20.

7. Damorou F., et al. "Epidémiologie de l'hypertension artérielle au CHU de Kara”. African Biomedicine 14 (2009): 95-102.
8. Agoudavi K., et al. "Rapport final de l'enquête STEPS Togo 2010". Ministère de la Santé Togo. (2012) www.sante.gouv.tg

9. Yao KH., et al. "Hypertension artérielle de Novo compliquée de l'adulte en milieu hospitalier noir Africain". Revue Internationale des Sciences Médicales d 13.2 (2011): 33-36.

10. Perrine AL., et al. "L'hypertension artérielle en France: prévalence, traitement et contrôle en 2015 et évolutions depuis 2006". Revue de Biologie Médicale 347 (2019): 75-85.

11. Cooper R., et al. "The prevalence of hypertension in seven populations of west African origin". American Journal of Public Health 87.2 (1997): 160-168.

12. Diallo B. "Profil épidémiologique de l'HTA en milieu hospitalier au CHR de Bamako au Mali. Etude prospective à propos de 110 cas". Médecine d'Afrique Noire 45 (2000): 346-312.

13. Ordunez P., et al. "Education, and Blood Pressure in Cuba". American Journal of Epidemiology 162.1 (2005): 49-56.

14. Atallah A., et al. "Prévalence et prise en charge de l'hypertension artérielle en Guadeloupe, France”. BEH 49.50 (2008): 486-489.

15. Yannoutsos A., et al. "Hypertension artérielle et diabète: quelle cible thérapeutique et quel choix de traitement?" Réalités en nutrition et en diabétologie 41 (2012): 29-34.

16. Tankeu AT., et al. "Spécificités de la prise en charge de l'hypertension artérielle chez le patient diabétique sub-saharien". Médecine des maladies Métaboliques 11.2 (2017): 148154.

17. Tesfaye F., et al. "Association between body mass index and blood pressure across three populations in Africa and Asia". Journal of Human Hypertension 21 (2007): 28-37.

18. Drabo YJ., et al. "Du traitement de l'HTA au centre hospitalier régional de Fada-gourma, à propos de110 cas". Médecine d'Afrique noire électronique 39 (1992): 36-41.

19. Bouramoue C. "Hypertension artérielle de l'adulte au centre hospitalier de Brazzaville-congo à propos de 4928 cas”. Médecine d'Afrique noire électronique 45 (2002): 587-59.

20. Goeh-Akue E., et al. "Hypertension artérielle en milieu rural au Togo: cas du District Sanitaire d'Agou”. Revue CAMES - Portails Des Revues Africaines 06 (2008): 65-69.

21. Twagirumukiza M. "Aspects de l'HTA au service de médecine interne au CHU de Burare-Rwanda: étude prospective à propos de 144 cas". Médecine d'Afrique Noire 50 (2003): 167-175. 
22. Djidjoho AS., et al. "Etude du risque cardiovasculaire absolu et des complications de l'hypertension artérielle dans une population de patients hypertendus à Cotonou". Journal de la Société de Biologie Clinique du Bénin 026 (2017): 35-40.

23. Drabo YJ., et al. "Les atteintes cardiaques du diabétique: Etude de260 diabétiques au CHN de Oaugadougou". Revue Africaine de Diabétologie 4 (1996): 5-7.

24. Longo-Mbenza B., et al. "The role of hemodynamic impairment and duration on diabétic cardiomyopathy and Hypertension in central Africans with atherosclerosis". Journal of Diabetes and its Complications 12 (2002): 146-152.

25. Ukoh VA. "Admission of hypertensive patients at the University of Benin Teaching Hospital, Nigeria". East African Medical Journal 84.7 (2007): 329-335.

26. Lengani A., et al. "Caractéristiques de l'atteinte rénale dans la morbidité hypertensive de l'adulte au Burkina Faso". Archives Des Maladies Du Coeur Et Des Vaisseaux 93 (2000): 1053-1057.

27. Bekemsi M. "HTA compliquée en milieu hospitalier à propos de 250 cas". Mémoire de Médecine Interne, Université de Lomé, Togo (2013): 76 pages.

28. Bogousslavsky J., et al. "Stroke Subtypes and Hypertension: Primary Hemorrhage vs Infarction, Large- vs Small-Artery Disease". Archives of Neurology 53.3 (1996): 265-269.

29. Pio M., et al. "Epidémiologie et étiologies des insuffisances cardiaques à Lomé". Pan African medical Journal (2014): 18.

\section{Assets from publication with us}

- Prompt Acknowledgement after receiving the article

- Thorough Double blinded peer review

- Rapid Publication

- Issue of Publication Certificate

- High visibility of your Published work

Website: www.actascientific.com/

Submit Article: www.actascientific.com/submission.php

Email us: editor@actascientific.com

Contact us: +919182824667 